DOI: https://doi.org/10.31073/mivg201902-208

Available at (PDF): http://mivg.iwpim.com.ua/index.php/mivg/article/view/208

UDC 504.4.06:504.53.06

\title{
DEVELOPMENT OF SCIENTIFIC BASIS FOR WATER MANAGEMENT IN AGROLANDSCAPES
} \author{
V.O. Bohaienko ${ }^{6}$, Ph.D. in technical sciences \\ ${ }^{1}$ Institute of water problems and land reclamation NAAS, Kyiv, Ukraine; \\ e-mail: mihailov1333@gmail.com \\ ${ }^{2}$ Institute of water problems and land reclamation NAAS, Kyiv, Ukraine; \\ https://orcid.org/0000-0002-2637-6538; e-mail: monitoring_protect@ukr.net \\ ${ }^{3}$ Institute of water problems and land reclamation NAAS, Kyiv, Ukraine; \\ https://orcid.org/0000-0002-2004-5359; e-mail: iuliia.danylenko@gmail.com \\ ${ }^{4}$ Institute of water problems and land reclamation NAAS, Kyiv, Ukraine; \\ https://orcid.org/0000-0003-4343-0054, e-mail: lutnizkii@ukr.net \\ ${ }^{5}$ Institute of water problems and land reclamation NAAS, Kyiv, Ukraine;

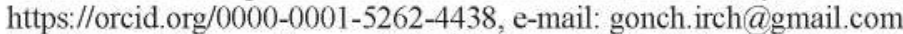 \\ ${ }^{6}$ Institute of Cybernetics. n.a. V.M. Glushkov NAS of Ukraine, Kyiv, Ukraine; \\ https://orcid.org/0000-0002-3317-9022; e-mail: sevab@ukr.net
}

Yu.O. Mikhailov ${ }^{1}$, doctor of technical sciences, A.M. Shevchenko ${ }^{2}$, Ph.D. in agricultural sciences, Iu.Yu. Danylenko ${ }^{3}$, Ph.D. in technical sciences, S.M. Liutnytskyi ${ }^{4}$, I.L. Goncharuk ${ }^{5}$,

Abstract. The paper presents the results of long term research aimed at resolving the problems of scientific support of integrated water resources management in Ukraine in the context of climate change. As one of the elements of scientific support, the integrated water resources management is considered in terms of water management plans development, both for the basin level and for territorial-administrative units. In particular, the hydrochemical spectrum is considered as an integral indicator of the chemical state of the object proved to have a close correlation between total water income and the elements of water balance. The results of the studies of surface and ground waters within the territories of Kherson and Rivne regions are presented. Based on the data on hydrochemical spectrum, correlation functions between its values and elements of water balance were obtained. A methodological approach to water balance calculations based on the obtained dependencies is described. The presented approach allows drafting balances, the observance of which will guarantee the rational use of water resources, based on their existing volume and additional limits. The results of the proposed approach testing are presented, in particular, when developing a plan for integrated water resources management in Kherson region. The results of testing show a significant influence of the structure of agrolandscapes on water balance, both on the regional scale and at the field level. A modification of the methodology for studying the influence of the structure of agrolandscapes on water balance is proposed taking into account the use of remote sensing data to assess the reliability of in-situ data and fill the gaps in field measurements. As a result of the analysis of spatial structure of agrolandscapes for the case of Rivne region, conclusions are drawn about the latitudinal change in the agrolandscapes, while for Kherson region the main indicator is the saturation of the territory with windbreak afforestation. The obtained maps of spatial distribution and correlation dependencies were used to assess and predict water resource potential of the territories, which characterizes the average level of natural and artificial moisture during growing season and determines the potential productivity of lands.

Key words: agrolandscape, water balance, hydrochemical spectrum, water resources management.

Relevance of the topic. Ukraine is a European country with a quantitative and qualitative deficit of water resources. Climate change manifest itself in increasing aridity, so the problem of controlling the rational use of water resources and restoring their reserves and quality is becoming increasingly relevant. The scientific support for sustainable balanced water use is at the forefront.

This approach partially satisfies the scientific substantiation of the national water policy, which derives from the methods of water resources control in the territories with different water resource potential. The latter can be characterized by the maximum possible flow of precipitation and water taken from all sources to a certain area to meet economic needs.

One of the methodological approaches under Water Framework Directive 2000/60/EC is integrated water resource management, which aims at coordinated management of water, land, energy and labor with sustainable economic and social well-being based on fairness and without harming the ecosystem. [1]. 
Integrated water management involves developing appropriate basin-level plans that justify the goals, methods and means of achieving them. Such plans are a strategy for the development of river basins aimed at achieving the required water status, sustainable water use, enhancing protection and improving the ecological status of water bodies and adjacent areas [2;3].

The peculiarities of water management in Ukraine require the development of such plans not only for river basins, but also for territorialadministrative units, branches of economy and individual objects of water use. The territorialadministrative principle of integrated water management allows to optimize the structure of water consumption or the expenditure part of water management balances, the basin one their resource part. Initially, the water policy of districts and oblasts is coordinated, taking into account the water management of all water consumers located in their territories, and as a result, the water need is assessed at the water delivery points. Subsequently, the capacity of the existing water resource potential of river basins to meet water needs of the required quality without environmental risk to aquatic ecosystems and populations is assessed.

The integrated water management from the authors' point of view can be based on the results of many years of theoretical and experimental research within the thematic plans of the Institute of Water Problems and Reclamation.

Hydrochemical parameters. Studies have shown that surface waters have a pronounced diversity of their chemical composition, due to various factors. The chemical spectrum, namely the chemical elements and their compounds, arranged in decreasing order of concentration, can be formalized by mathematical expression

$$
C_{i}^{j}=a_{j} e^{-b_{j} k_{i}^{j}},
$$

where $C_{i}^{j}$ - the concentration of the $i$-th element of the $j$-th spectral group;

$a_{j}$ and $b_{j}$ - empirical coefficients or spectrum parameters;

$k_{i}^{j}$ - the order number of the i-th element of the $j$-th group of this spectrum.

The multiplier factor $a_{j}$ is equal to the maximum possible concentration of the chemical element (compound). It leads its spectral group and is a basic element as well as practically a constant. The coefficient $b_{j}$ characterizes the intensity the concentration of other elements of a given spectral group decreases.

The hydrochemical spectrum is an integral indicator of the chemical status of a water body. It characterizes the maximum possible concen- tration of anions and cations in water and the nature of their change at different intensity of water exchange [4]. Integrated water management reliably promotes their quality, provided that there is sufficient (at least 1.2) coefficient of seasonal water exchange in the catchment area and in reservoirs. Such water exchange must be ensured by maintaining an appropriate water balance structure.

Our studies have also demonstrated the existence of close correlation relationships between total water abstraction, water balance elements and hydrochemical spectrum parameters. A certain total flow of water into a site or water body always corresponds to certain values of the expenditure elements of the balance and the parameters of the spectrum.

Formally, that can be described by empirical correlation functions

$$
\begin{gathered}
\Delta W=F(X+P), \\
C_{i}^{j}=\Omega\left(K_{v}\right),
\end{gathered}
$$

where $\Delta W$ - change in water reserves in the balance space;

$(X+P)$ - total water inflow into the balance space as a result of precipitation and water extraction for all economic needs;

$K_{v}$ - coefficient of water exchange intensity.

Based on the results of chemical analysis of water samples using the methods of mathematical statistics it is determined hydrochemical spectra, namely empirical curves, which most accurately describe the distribution of chemical elements and compounds in the order of decreasing their concentration.

The data of geospatial analysis of the chemical composition of water samples taken in the territory of Kherson and Rivne regions in summer 2012 were summarized (Fig. 1).

According to the ratio of anions and cations, the territory of the Rivne region can be divided into two regions: northern - the Polissia and southern - the Forest-Steppe, which are different in sulfate content. In forest-steppe regions their content is on average $14.5 \mathrm{mg} / \mathrm{dm}^{3}$, in Polissia $44.8 \mathrm{mg} / \mathrm{dm}^{3}$.

The surface waters of the Rivne region are saturated with significant iron content due to the swampiness of the territory of the region, and as a result of that there is a large amount of humus substances in the surface waters that have a weak acidic reaction and contribute to dissolving iron and its transition into a colloidal state.

A significant difference in the chemical composition of the surface and groundwater of the Kherson region was specified. So in surface 

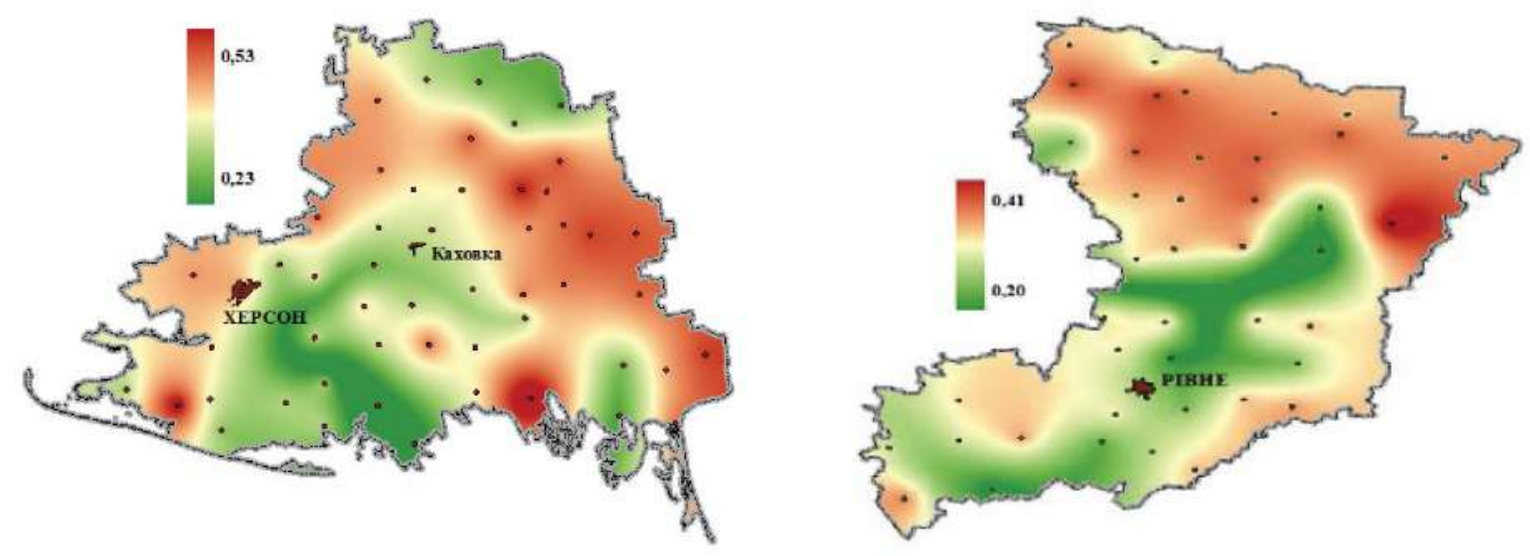

Fig. 1. Spatial distribution of anions and cations ratio in the water of Kherson and Rivne regions

waters calcium hydrocarbonate prevails, and in underground ones - chloride and sodium sulfate, which are more toxic salts to plants. In addition, the mineralization of surface water is much smaller than of groundwater.

Considering that natural waters are solutions with quasi-stationary chemical compositions due to the geochemical conditions of their formation, their azonality is observed. The ratio of cations and anions may indicate some local processes of artificial nature, in other words man-made pollution.

The chemical composition of the surface waters of both regions is almost the same. The slight spatial changes in the content of chemical elements in surface waters are explained by the natural chemical metamorphism of the natural waters of Ukraine from north to south.

Studies of hydrochemical spectra have shown that their baseline parameters are much higher for groundwater than for surface water (Table 1). That is, the maximum possible concentration of anions and cations in groundwater is much higher.

The results of the study of the spatial changes in the chemical composition of surface waters in the Dnieper basin testify to the distinct homogeneity of their hydrochemical spectra [4], which gives reason to limit in practice the observations of the changes in the chemical composition of water by the results of the analysis of its samples taken in separate water bodies of the river basin.

Upon accumulating the experimental data and based on the results of the geospatial analysis of the hydrochemical spectra, the number of such points can be reduced tenfold without a significant negative impact on the reliability of the final result.

By means of correlation functions, for example, a water balance can be drawn up, the maintenance of which will guarantee the rational use of water resources, based on their available volume and restrictions on the total water flow, filtration losses, surface runoff (discharges).

The water balance in the graphical representation is a straight-line function that cuts the average over the observation period sum of the cost elements on the y-axis. The tangent of the slope graph is equal to the ratio of costs to the flow of water, that is, the coefficient of water supply. In the case of curvilinear function, the same conclusions can be drawn with respect to tangents.

The scope of this methodological approach is limited only by the ability to obtain the source data. At least, there is a need for precipitation data, abstraction of water from all sources in volumes

1. Parameters of hydrochemical water spectra

\begin{tabular}{|c|c|c|c|c|c|c|c|}
\hline \multirow{3}{*}{ Region } & \multirow{2}{*}{$\begin{array}{c}\text { Spectral } \\
\text { groups and } \\
\text { indicators }\end{array}$} & \multicolumn{6}{|c|}{ Determination factor } \\
\cline { 3 - 8 } & & \multicolumn{2}{|c|}{$0,0-0,4$} & \multicolumn{2}{|c|}{$0,4-0,8$} & \multicolumn{2}{c|}{$0,8-1,0$} \\
\cline { 3 - 8 } & & Values of hydrochemical spectra parameters by spectral groups \\
\cline { 3 - 8 } & Anions & - & - & 780 & 1,49 & 1563 & 1,68 \\
\hline \multirow{3}{*}{ Rivne } & Cations & 106 & 0,70 & 56,5 & 0,70 & 142 & 0,95 \\
\cline { 2 - 8 } & Heavy metals & - & - & 0,76 & 0,76 & 3,83 & 1,16 \\
\hline \multirow{2}{*}{$\begin{array}{c}\text { Kherson } \\
\text { (surface waters) }\end{array}$} & Anions & 17,7 & 0,28 & 1671 & 1,61 & 7368 & 2,18 \\
\cline { 2 - 8 } & Cations & 28,25 & 0,01 & 103,21 & 0,89 & 134,5 & 0,93 \\
\hline \multirow{2}{*}{$\begin{array}{c}\text { Kherson (under- } \\
\text { ground waters) }\end{array}$} & Anions & - & - & 116984 & 3,13 & 1168113 & 3,08 \\
\cline { 2 - 8 } & Cations & 687 & 0,42 & 2084 & 1,07 & 1285 & 1,11 \\
\hline
\end{tabular}


comparable to precipitation, and more. It is also desirable to have observations of groundwater level fluctuations and lack of moisture in the air.

The method of water balance calculations was more carefully described by us in [5]. It was tested in the preparation and implementation of the integrated water management plan of Kherson region and in most of the authors' studies, which yielded the following results.

Influence of agro-landscape structure on water balance elements. The structural elements of agro-landscapes significantly influence the formation of water resources. Modern agro-landscapes are a combination of typical elements of agro-ecosystems, so it is advisable to separate them.

Our experimental studies confirm the high positive impact of forests, forest strips and meadows on the formation of water resources. If in forests, forest strips and meadows (natural constituents of agro-landscapes) all precipitation of the cold period is absorbed by the soil, that is why the surface runoff is absent at this time, on arable lands and pastures (artificially transformed elements), the loss of winter precipitation due to the snow displacement and the evapotranspiration increase by $25-50 \mathrm{~mm}$, the filtration decreases by about $100 \mathrm{~mm}$, and the surface runoff increases by $30-85 \mathrm{~mm}[6 ; 7]$.

Within the landscapes, data layers can be identified for forest plantations, reclaimed lands, bogs and wetlands. The impact of rivers and their floodplains on adjacent farmland should be another point.

There is a need for some changes in the field research methodology for the influence of agrolandscapes structure on the water balance. The essence of this is to measure the moisture content of the soil to assess the reliability of the source information obtained from remote sensing, as well as to assess the close correlation between calculated and measured indicators.
In order to determine soil moisture, it is advisable to use a thermostatic-weight method with soil sampling every $10 \mathrm{~cm}$ up to a depth of $1.0 \mathrm{~m}$ in repetition, which can be increased when the study area and the mixed character of the agro-landscape structure within it increase.

Moisture soil sampling is performed for the areas covered with natural vegetation at the end of a long rainless period. The results of the analysis of soil moisture data and the decoding of remote sensing data show a sufficiently close correlation between moisture reserves in the meter layer of soil and the normalized difference vegetation index (Fig. 3). This approach enables evaluate the nature of the spatial distribution of the field soil moisture.

Evaluation of the results of field studies, in particular their representativeness, is carried out according to the data of remote sensing of the experimental area from the satellites.

The decrease in moisture reserves in the root soil layer indicates a deficit in the water balance and vice versa. The isolines of water reserves enable to identify agricultural landscapes with typical conditions for the formation of soil water balance.

To typify the territory the authors used two sets of thematic layers - structural elements and values of vegetation indices.

For example, in the territory of the Rivne region it is possible to distinguish the areas (Fig. 3) with a size of $10 \times 10 \mathrm{~km}$, where the same types of landscapes prevail. As a result, a typification map of agricultural landscaping was built. The following types can be distinguished:

- the first is the areas, in which natural landscapes dominate, where forests, swamps, floodplains occupy more than $60 \%$ of the total area;

- the second is the intermediate (transitional) areas, in the structure of which natural landscapes and agricultural landscapes are almost equal;

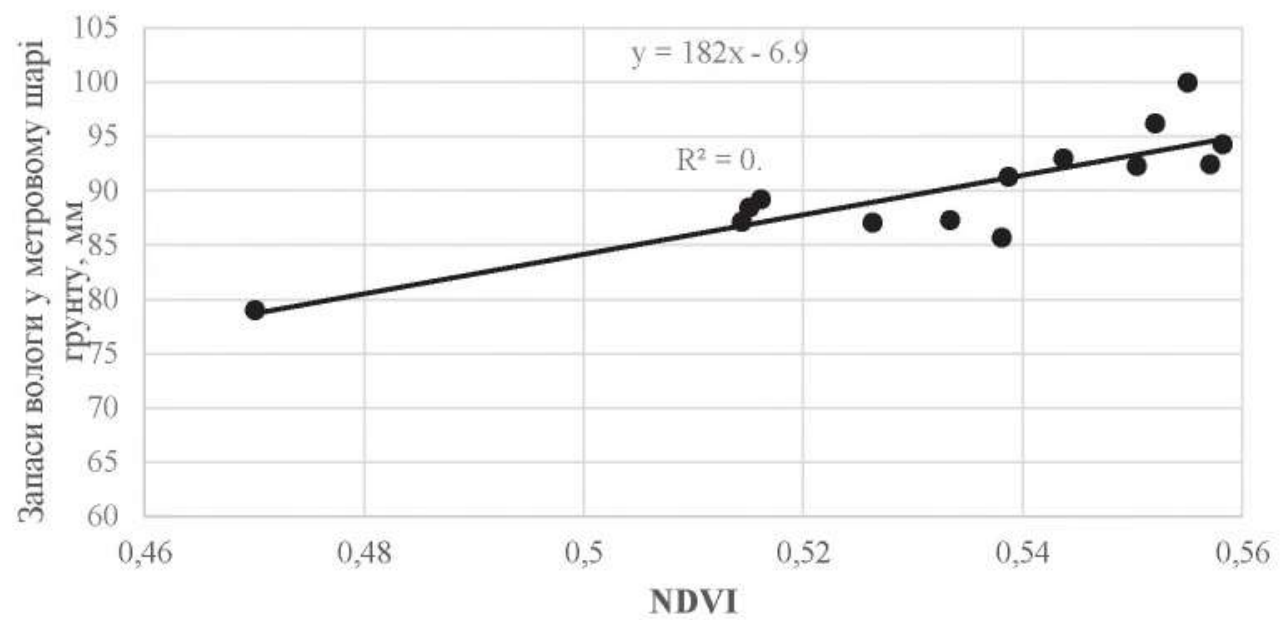

Fig. 2. Correlation of change in moisture reserves in soil meter layer and normalized difference vegetation index 


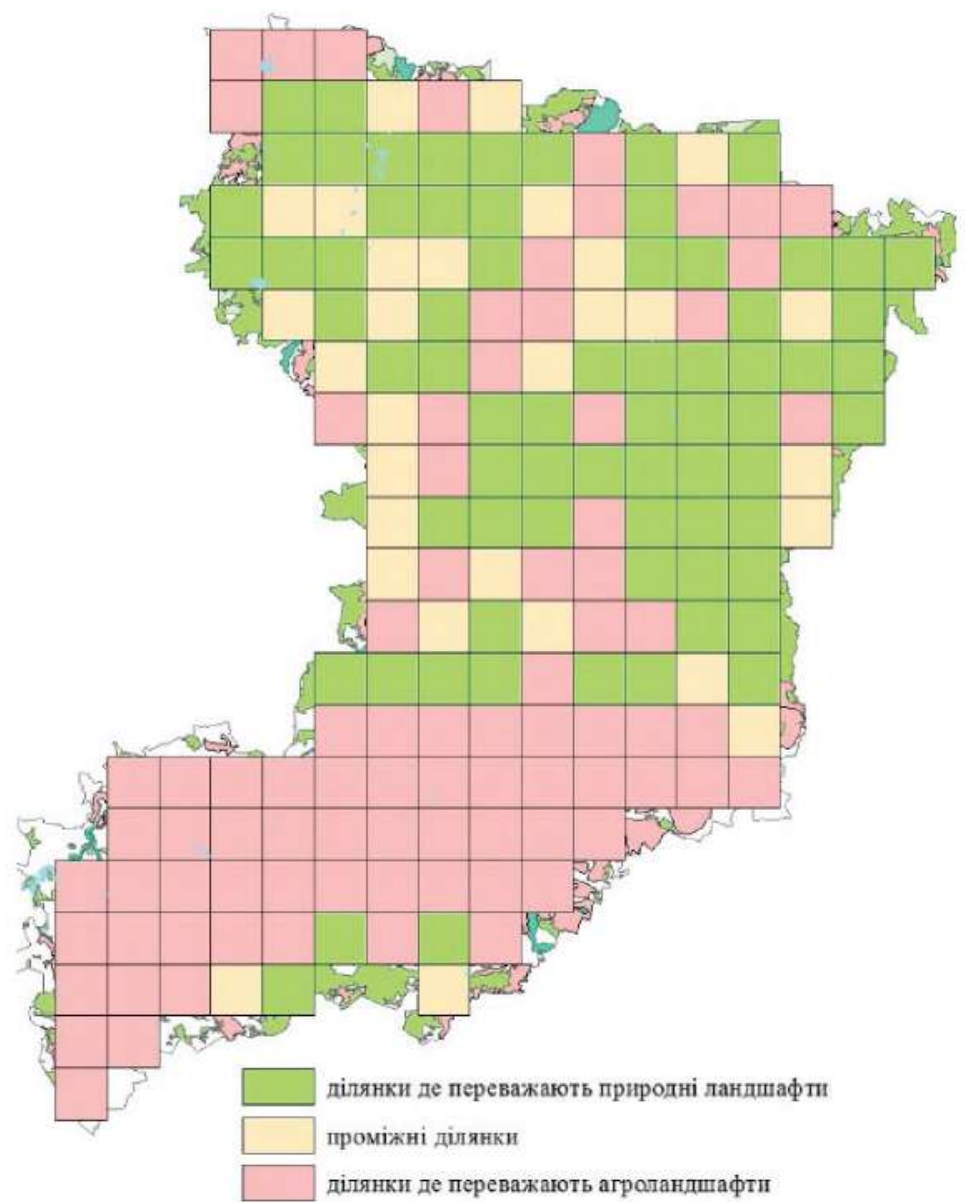

Fig. 3. Typification of agricultural landscapes in Rivne region

- the third is the areas, in which agricultural landscapes dominate, where agricultural fields and land reclamation systems occupy more than $60 \%$ of the total area.

This territory is typical for most areas of the Polissya zone of Ukraine, which makes it possible to fairly estimate the processes of formation of water resources in agrolandscapes of the humid zone, spatial patterns of formation and regulation processes of water balance.

For the conditions of the pilot territory of the Kherson region, given the natural and economic specificity of the steppe zone, forest strips are the main structural element of agrolandscapes. Therefore, the classification of such territories by the structural elements of agrolandscapes is advisable to make according to their forest saturation index.

Agrolandscapes are complex natural-technical systems. In most cases, when studying, and especially when investigating their influence on the processes of water formation and use, it is possible to operate a finite number of interconnected parts (subsystems). The purpose of identifying such subsystems is obtaining typical areas for which the spatial structure of agricultural landscapes can be experimentally evaluated and the nature of its relationship with the factors of qualitative and quantitative formation of surface water resources can be determined.

The basis for identifying larger spatial structures is the unification of plots on the principle of existing repetition of such structural elements as forests, swamps, fields, reclamation systems, forest strips, etc.

The example of the result of such an analysis of the spatial structure of agro-landscapes in the pilot territory of the Rivne region is the conclusion about the latitudinal change of agro-landscapes.

Thus, in the northern part of the region agricultural landscapes of natural origin dominate; in the eastern part - natural agro-landscapes of forests and swamps. Their total area exceeds $70 \%$. Forests also dominate in the western part, but about $40 \%$ of this territory belongs to artificial elements of agricultural landscapes.

In the central part of the region artificial agricultural landscapes with land reclamation systems, which occupy almost $60 \%$ of the territory, dominate. In the south of the region the artificial agrolandscapes also dominate, but field agro-landscapes (more than $65 \%$ of the territory) predominate in this territory. 
Similar studies in the territory of the Kherson region show that the spatial structure of agricultural landscapes under irrigation conditions has two main types: 1) with systematic irrigation, but lack of forests and forest strips; 2) with developed irrigation in the midst of the developed timber component of irrigated landscapes.

The agro-resource potential of the rural territories of Ukraine is closely related to their water-resource potential. The latter characterizes the average level of natural and artificial moistening of rural areas during the growing season, which determines their potential productivity.

Water balance of agricultural landscapes. Sustainable agriculture in many regions of Ukraine requires measures for artificial regulating soil water regime. The success of water reclamation, in turn, depends on the availability of reliable information about the geospatial distribution of water resources, which allows with sufficient accuracy to calculate the soil moisture deficit or its excess and, accordingly, to control the water resources of a certain area, redistribute irrigation water or regulate drainage systems operation.

Based on the results of the researches of 2011-2015 it was identified the patterns of spatial change in water resource potential of rural territories, established the basic patterns of their spatial and temporal variation along with their visualization on maps until 2030. The research was based on state water monitoring data, space imagery and meteorological data.

According to the estimation of the water balance of rural territories, the water resource potential is equal to the sum of precipitation and water volumes entering the balance space due to its collection for economic needs from surface and underground (soil) sources [8]. This addresses the issue of assessing and forecasting the water resource potential of agricultural areas and changing it to develop measures for the rational use and protection of water resources. The example of such estimation is given in Fig. 4.

For rural areas, the boundaries of which usually do not coincide with the catchments (basins) of rivers, and when calculating for the periods shorter than the hydrological year, it is necessary to add precipitation to the water reserves. The total flow of water along with the precipitation (except for the transit runoff in rivers and canals) is a water resource potential of the territory.

When drawing up the water balance for a hydrological year, water resources should not include precipitation, which is almost completely converted to river runoff.

Water amount should be considered to be available for use, the removal of which from natural or artificial circulation will not lead to negative environmental impacts or increase the economic cost and the restoration of fresh water reserves. Water reserves available for use are also limited by its quality, which in turn is determined by its chemical composition.

Water reserves and volumes of its use vary greatly in time and space, so the following operations should be supplemented to the water integrated management:

- in the first stage, it is planned to fulfill a differentiated by the territories and time intervals,

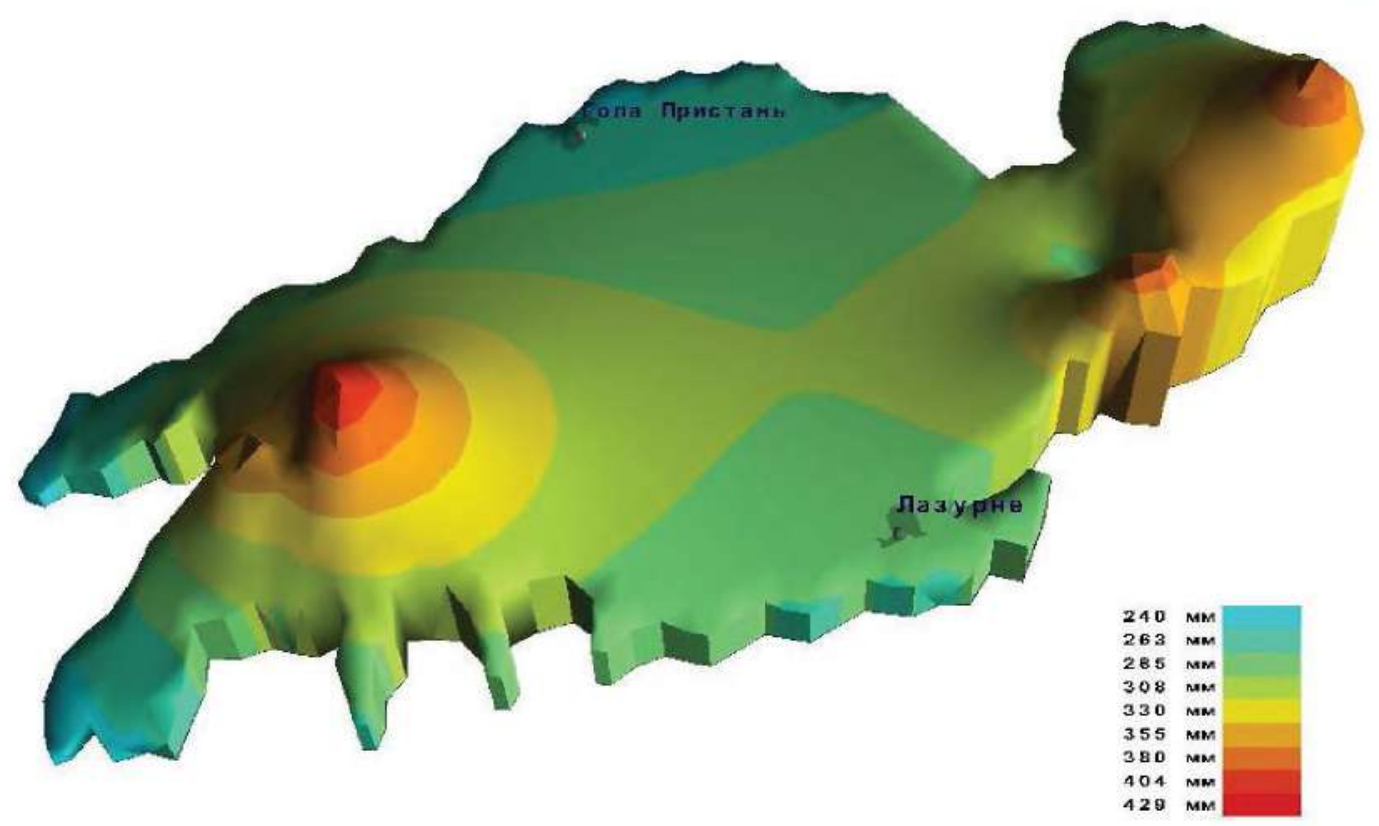

Fig. 4. Water resource potential of the Krasnoznamyansky irrigated land area in 2010 
as well as by individual groups of consumers, assessment of water resource potential, its retrospective and prospective changes in conditions of different anthropogenic load, development of necessary measures for its optimization and stabilization at an environmentally safe level;

- in the second stage the tasks of integrating the results of the above estimates within the river basin or a specific territorial or territorial-administrative unit are solved.

The essence of integrated water management is to develop and implement the measures aimed at achieving "good" water status for specific water objects, improving the quantitative characteristics of water use by approximating the components of the current water balance of the territory in accordance with their objectives, when the followings are minimized: technologically unreasonable losses of water for irreversible water consumption, filtration and discharges; volumes of insufficiently treated return water; total water abstraction for the needs of the industries in the region etc.
Conclusion. The authors consider it advisable to continue scientific research on the assessment of the impact of the spatial structure of agrolandscapes on the quantity and quality of water resources in different farming systems that is related to the need for geospatial analysis of complex processes of formation and use of water resources.

Anthropogenic changes in the landscapes within river catchments without taking into account the structure of such formations adversely affect the restoration and self-regulatory capacity of river basin ecosystems, and as a consequence of virtually all ecosystems and transformed agro- and urban landscapes. Along with climate change, this causes deterioration of territories and intense aridization.

A necessary area of research is to develop the basic principles of streamlining the spatial structure of agricultural landscapes within river catchment areas, to assess the impact of landscape components on the formation and distribution of water resources, depending on the area of their economic use.

\section{References}

1. Directive 2000/60/EC of the European Parliament and the Council. Retrived from https:// eur-lex.europa.eu/resource.$h t m l$ ?uri $=$ cellar:5c835afb-2ec6-4577-bdf8-756d3d694eeb.0004.02/ DOC $1 \&$ format=PDF.

2. Metodychni rekomendatsiyi $\mathrm{z}$ pytan intehrovanoho upravlinnya vodnymy resursamy, zberezhennya vodno-bolotnoho riznomanittya, stvorennya ekomerezhi ta orhanichnoho zemlerobstva [Methodological recommendations for integrated management of water resources, saving wetlands diversity, creating ecological network, and organic agriculture]. (2011). Kyiv: Chornomorska programa Vetlands Interneshnl. [in Ukrainian]. Retrieved from http://archive.wetlands.org/Portals/0/ Methodical\%20Recommendations.pdf

3. Romashchenko, M.I, Mykhailov, Yu.O., Lutnitsky, S.M. \& Danylenko, Iu.Yu. (2011). Udoskonalennya intehrovanoho upravlinnya vodnymy resursamy Ukrayiny za baseynovym pryntsypom [Improvement of integrated water management on basin principle]. Melioratsiya i vodne hospodarstvo, 99, 169-179. [in Ukrainian].

4. Romashchenko, M.I, Mykhailov, Yu.O., Stashuk, V.A., Lutnitsky, S.M. \& Mavliutdinova, I.A (2008). Formuvannya hidrokhimichnoho spektru r. Dnipra pid vplyvom sil's'kohospodars'kykh stokiv [Formation of hydrochemical spectrum of Dnipro river under the influence of waste water runoff]. Melioratsiya i vodne hospodarstvo, 96, 14-24. [in Ukrainian].

5. Mykhailov, Yu.O., Shevchenko, A.M., Danylenko, Iu.Yu., Lutnitsky, S.M. \& Bohaienko, V.O. (2016). Vodnyy balans yak forma stsenariyu upravlinnya vykorystannyam vodnykh resursiv v umovakh zroshennya [Water balance as the form of water use management under irrigation]. Melioratsiya i vodne hospodarstvo, 104, 10-15. [in Ukrainian].

6. Mykhailov, Yu.O. \& Vradin, S.O. (1999). Optymizatsiya vodnoho rezhymu ahrolandshaftiv v umovakh zroshennya. [Optimization of water regime in agrolandscapes under irrigation] Melioratsiya i vodne hospodarstvo, $86,53-58$. [in Ukrainian].

7. Mykhailov, Yu.O., Danylenkoю, Iu.Yu. \& Lutnitsky, S.M. (2010) Melioratyvni vlastyvosti ahrolandshaftiv Ukrayiny [Reclamative properties of agrolandscapes in Ukraine] Melioratsiya i vodne hospodarstvo, 98, 9-19. [in Ukrainian].

8. Mykhailov, Yu.O., Danylenko, Iu.Yu. \& Lutnitsky, S.M. (2013). Otsinyuvannya vodoresursnoho potentsialu sil's'kykh terytoriy [Assessment of water potential on rural areas]. Melioratsiya i vodne hospodarstvo, 100, 163-170. [in Ukrainian]. 
Ю.А. Михайлов, А.Н. Шевченко, Ю.Ю. Даниленко, С.Н. Лютницкий, И.Л. Гончарук, В.А. Богаенко Развитие научных основ управления водными ресурсами в агроландшафтах

Аннотация. В работе представлены результаты многолетних исследований связанньх с решением проблем научного обеспечения интегрированного управления водными ресурсами в Украине в условиях изменений климата. Среди элементов научного обеспечения интегрированное управление водными ресурсами рассматривается в части разработки планов управления, как на уровне бассейнов, так и территориально-административных единиц. В частности, в качестве интегрального показателя химического состояния объекта рассматривается гидрохимический спектр, который, как доказано, имеет тесную корреляционную связь с суммарным водопоступлением и элементами водного баланса. Приводятся результаты исследований поверхностных и подземных вод для территорий Херсонской и Ровенской областей. На основе данных о гидрохимических спектрах построены корреляционные функции между их значениями и элементами водного баланса. Описан методический подход к водобалансовым расчетам на основе полученных зависимостей, который позволяет составлять балансы, соблюдение которых будет гарантировать рациональное использование водных ресурсов, исходя из их суцествуючего объёма и дополнительных ограничений. Представлены результаты апробаиии предложенного подхода, в частности при разработке плана интегрированного управления водными ресурсами Херсонской области, которые показывают суцественное влияние структуры агроландиафтов на водный баланс, как в региональном маситабе, так и на уровне поля. Предложена модификация методики исследования влияния структуры агроландиафтов наводный баланс с учетом использования данньх дистаниионного зондирования для оченки достоверности измеренных данных и восполнения пробелов в ряде измерений. Приведены построенные карты типизсиии агроландиафтов, которье были использованы для выявления отличий коррелячионных функций между данными дистанционного зондирования и элементами водного балансу для разных территорий. В результате анализа пространственной структуры агроландиафтов Ровенской области сделано выводы о ииротном изменении агроландиафтов, при том, что для Херсонской области приниипиальным является показатель насыиеености территории лесными насаждениями. Полученные карты пространственного распределения и корреляционные зависимости были использованы для оченки и прогнозирования водоресурсного потенииала территорий, который характеризирует средний за период вегетации уровень естественного и искусственного увлажнения и обуславливает потенциальную продуктивность угодий.

Ключевые слова: агроландиафт, водный баланс, гидрохимический спектр, управление водными ресурсами.

Ю.О. Михайлов, А.М. Шевченко, Ю.Ю. Даниленко, С.Н. Лютницький, І.Л. Гончарук, В.А. Богаєнко Розвиток наукових основ управління водними ресурсами в агроландшафтах

Анотація. В роботі представлені результати багаторічних досліджень пов'язаних з вирішенням проблем наукового забезпечення інтегрованого управління водними ресурсами в Украӥні в умовсх змін клімату. Серед елементів наукового забезпечення інтегроване управління водними ресурсами розглядається в частині розробки планів управління, як на рівні басейнів, так і на рівні територіально-адміністративних одиниць. Зокрема, як інтегральний показник хімічного стану об'єкта розглядається гідрохімічний спектр, який, як доведено, мас тісний кореляційний зв язок з сумарним водонадходжсенням i елементами водного балансу. Наводяться результати досліджень поверхневих $і$ підземни вод для територій Херсонської та Рівненської областей. На основі даних про гідрохімічні спектри побудовані корелячійні функиії між їх значеннями і елементами водного балансу. Описано методичний підхід до водобалансових розрахунків на основі отриманих залежностей, який дозволяе складати баланси, дотримання яких гарантуватиме рачіональне використання водних ресурсів, виходячи з їхнього існуючого обсягу і додаткових обмељень. Представлені результати апробачії запропонованого підходу, зокрема при розробчі плану інтегрованого управління водними ресурсами Херсонської області, які показують істотний вплив структури агроландиафтів на водний баланс, як в регіональному маситабі, так $і$ на рівні поля. Запропоновано модифікачію методики дослідження впливу структури агроландиафтів на водний баланс з урсхуванням використання даних дистаниійного зондування для оцінки достовірності даних вимірювань і заповнення прогалин у ряді вимірювань. Наведено побудовані карти типізсиії агроландиафтів, які були використані для виявлення відмінностей кореляційних функиій між даними дистаниійного зондування та елементами водного балансу для різних територій. На основі аналізу просторової структури агроландиафтів Рівненській області зроблено висновки про ииротну зміну агроландиафтів, тоді, як для Херсонської області принциповим є показник насиченості території лісовими насадженнями. Отримані карти просторового розподілу і корелячійні залежності були використані для очінки і прогнозування водоресурсного потениіалу територій, який характеризує середній за період вегетації рівень природного та итучного зволоження і обумовлює потенчійну продуктивність угідь.

Ключові слова: агроландиафт, водний баланс, гідрохімічний спектр, управління водними ресурсами. 